\title{
Implementasi Fungsi Pengaturan serta Pengawasan pada Bank Indonesia dan Otoritas Jasa Keuangan (OJK) terhadap Perbankan.
}

\author{
Rustam Magun Pikahulan \\ IAIN Pare-pare, Email: rustammagunpikahulan@iainpare.ac.id
}

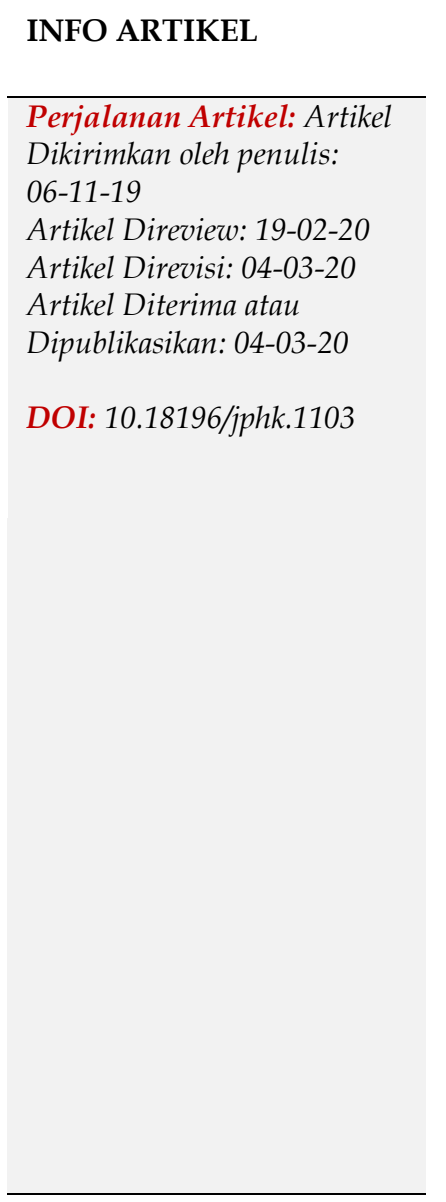

\begin{abstract}
ABSTRAK
Sebelum terbentuknya Otoritas Jasa Keuangan (OJK), untuk tercapainya sebuah sistem perbankan yang sehat dan stabil, bank dalam melaksanakan tugasnya tidak luput dari pengawasan Bank Indonesia yang bertindak selaku bank sentral. Kedudukan Bank Indonesia sebagai bank sentral, mempunyai tujuan untuk mencapai dan memelihara kestabilan nilai rupiah. Penelitian hukum normative ini mengkaji dua hal yaitu pelaksanaan fungsi pengaturan dan pengawasan oleh Bank Indonesia terhadap perbankan setelah dibentuk dan pelaksanaan fungsi pengaturan dan pengawasan oleh Otoritas Jasa Kewenangan (OJK) terhadap perbankan. Bank Indonesia secara yuridis masih memiliki otoritas dalam pengaturan dan pengawasan perbankan walaupun telah hadir Otoritas Jasa Keuangan (OJK). Hal ini dikarenakan, Pengawasan macroprudential tetap saja menjadi kewenagan dari Bank Indonesia, sebagaimana diatur dalam penjelasan Pasal 7 Undang-Undang OJK mengenai tugas dan wewenang Bank Indonesia, yang menyatakan bahwa lingkup pengaturan dan pengawasan macroprudential merupakan tugas dan wewenang Bank Indonesia. Sedangkan fungsi Otoritas Jasa Keuangan (OJK) adalah penyelengaraan sistem pengaturan dan pengawasan yang terintegrasi terhadap keseluruhan kegiatan di sektor keuangan dalam hal termasuk pada sektor perbankan.
\end{abstract}

Kata kunci: Bank Indonesia, Otoritas Jasa Keuangan (OJK), Perbankan

\section{Pendahuluan}

Kehadiran sebuah bank sangat erat kaitannya dengan perkembangan di bidang perdagangan. Kehidupan dunia modern saat ini tidak dapat dilepaskan dan bahkan sering tergantung pada aktivitas dan jasa perbankan. Hal ini sama seperti yang terjadi di Indonesia, bahwa perkembangan perekonomian dan perdangangan sanagat bergantung pada kinerja perbankan.oleh karena itu, dengan kehadirannya banyak lembaga keuangan perbankan maka, pemerintah Indonesia membuat kebijakan tentang pengawasan terhadap kinerja bank. Ketentuan Pasal 34 Undang-Undang Republik Indonesia Nomor 23 Tahun 1999 tentang Bank Indonesia yang telah dirubah Undang-Undang Nomor 3 Tahun 2004 tentang Bank Indonesia dan dirubah dengan 
Undang Undang Nomor 6 Tahun 2009 yang mengamanatkan pembentukan lembaga pengawasan sektor jasa keuangan yang mencakup perbankan, asuransi, dana pensiun, sekuritas, modal ventura, dan perusahaan pembiayaan serta badan-badan yang menyelenggarakan dana-dana masyarakat.

Sebelum terbentuknya Otoritas Jasa Keuangan (OJK), untuk tercapainya sebuah sistem perbankan yang sehat dan stabil, bank dalam melaksanakan tugasnya tidak luput dari pengawasan Bank Indonesia yang bertindak selaku bank sentral. Kedudukan Bank Indonesia sebagai bank sentral, mempunyai tujuan untuk mencapai dan memelihara kestabilan nilai rupiah. Demi mewujudkan tujuannya tersebut, Bank Indonesia memiliki tugas sebagaimana yang dicantumkan dalam Pasal 8 UndangUndang Nomor 23 Tahun 1999, yaitu sebagai berikut:

a) Menetapkan dan melaksanakan kebijakan moneter;

b) Mengatur dan menjaga kelancaran sistem pembayaran;

c) Mengatur dan mengawasi bank.

Kebijakan ini diambil dikarenakan banyaknya permasalahan di sektor perbankan yang terjadi krisis yang berdampak 21 (dua puluh satu) bank swasta nasional yang krisis dilikuidasi oleh Bank Indonesia, yang ditemukan berbagai penyimpangan sehingga banyak yang mempertanyakan pengawasan Bank Indonesia. Begitu juga adanya peristiwa yang mengejutkan bahwa Bank Century ditetapkan Bank Indonesia sebagai bank gagal berdampak sistemik. Banyaknya permasalahan di sektor jasa keuangan di bidang perbankan yang dapat mengganggu stabilitas sistem keuangan semakin mendorong diperlukannya pembentukan lembaga pengawasan di sektor jasa keuangan yang terintegrasi. ${ }^{1}$ Fungsi, tugas dan wewenang pengaturan dan pengawasan kegiatan jasa keuangan di sektor Perbankan beralih dari Bank Indonesia ke Otoritas Jasa Keuangan. Setiap pejabat selalu membuat kebijakan dalam berbagai bidang. Kebijakan (policy) diberi arti yang berbeda oleh Harold D. Lasswell dan Abraham Keplan yang mengartikan kebijakan sebagai "a projected program of goals, values and practices". Kebijakan dimaknai sebagai serangkaian tindakan yang ditetapkan dan dilaksanakan atau tidak dilaksanakan oleh pemerintah yang mempunyai tujuan atau berorientasi pada tujuan tertentu demi kepentingan seluruh masyarakat. ${ }^{2}$

Perbankan Indonesia telah memasuki babak baru, dengan diundangkannya Undang-Undang Otoritas Jasa Keuangan (selanjutnya disebut dengan OJK) pada Tanggal 22 November 2011. Dimana pengaturan dan pengawasan sektor perbankan tidak lagi berada pada Bank Indonesia namun dialihkan kepada otoritas jasa keuangan yakni sebuah lembaga independen yang mempunyai fungsi, tugas dan wewenang

1 Surti Yustiantia, Kewenangan Pengaturan Dan Pengawasan Perbankan Oleh Bank Indonesia Dan Otoritas Jasa Keuangan (OJK), ACTA DIURNAL Volume 1, Nomor 1, Desember 2017, hlm. 4

2 Zulfi Diane Zaini, "Hubungan Hukum Bank Indonesia Sebagai Bank Sentral Dengan Otoritas Jasa Keuangan (OJK) Pasca Pengalihan Fungsi Perbankan", Jurnal Media Hukum, Vol. 20 No. 2, Desember 2013, hlm. 377. 
untuk melakukan pengaturan, pengawasan pemeriksaan dan penyidikan terhadap jasa keuangan di Indonesia, dengan demikian seluruh kegiatan jasa keuangan sektor perbankan, pasar modal, asuransi, dana pensiun, lembaga pembiayaan dan lembaga jasa keuangan lainnya ada dalam kewenangan OJK. ${ }^{3}$ Keputusan untuk menempatkan fungsi pengawasan perbankan di bank sentral atau memilih menempatkan dalam sebuah badan yang independen diluar bank sentral pada masing-masing. pengawasan perbankan di Indonesia tidak lagi pada Bank Indonesia namun dipindahkan ke dalam sebuah badan independen yang mempunyai dasar yuridis pada Undang-Undang Nomor 3 Tahun 2004 tentang Perubahan Atas Undang-Undang Nomor 23 Tahun 1999 tentang Bank Indonesia. ${ }^{4}$

Otoritas Jasa Keuangan di Indonesia berdasarkan pada Pasal 34 UndangUndang Nomor 3 Tahun 2004 tentang Perubahan Atas Undang-undang Nomor 23 Tahun 1999 tentang Bank Indonesia (BI). Pemerintah diamanatkan membentuk lembaga pengawas sektor jasa keuangan yang independen, selambat-lambatnya akhir tahun 2010 dengan nama Otoritas Jasa Keuangan (OJK). Lembaga ini bertugas mengawasi industri perbankan, asuransi, dana pensiun, pasar modal, modal ventura, dan perusahaan pembiayaan, serta badan-badan lain yang menyelenggarakan pengelolaan dana masyarakat. Otoritas Jasa Keuangan memiliki kewenangan yang luas yakni membuat peraturan di bidang jasa keuangan, memberi dan mencabut izin persetujuan dan lain-lain, memperoleh laporan periodik dan informasi industri jasa keuangan; mengenakan sanksi administratif, melakukan pemeriksaan, melakukan penyidikan atas pelanggaran UU, memberikan arahan atau perintah tertulis, menunjuk pengelola statuter, mewajibkan pengalihan usaha demi menjaga kepentingan nasabah, mencegah kejahatan di bidang keuangan; dan mengatur pengendalian lembaga keuangan.

Fungsi pengaturan dan pengawasan tersebut tidaklah sepenuhnya diberikan kepada OJK. Akan tetapi OJK tetap bekerjasama dengan BI dan memiliki kewenangannya masing-masing dalam menjalankan fungsi pengaturan dan pengawasan. Pengaturan dan Pengawasan kelembagaan, kesehatan, aspek kehatihatian, dan pemeriksa bank merupakan lingkup microprudential yang menjadi tugas dan wewenang OJK. Adapun lingkup pengaturan dan pengawasan microprudential, OJK berkordinasi dengan BI untuk melakukan himbauan moral (moral suasion) kepada perbankan. ${ }^{5}$ Oleh karena itu berangkat dari adanya kerjasama antara Bank Indonesia dan OJK, dalam pengawasan terhadap lembaga keuangan dalam hal ini termasuk perbankan. Maka, perlu adanya kajian yang mendalam terkait dengan pengaturan dan

3 Lina Maulidiana, Fungsi Otoritas Jasa Keuangan Sebagai Lembaga Pengawas Perbankan Nasional Di Indonesia, Jurnal Keadilan Progresif, Volume 5 Nomor 1 Maret 2014

4 Permadi Gandapradja, 2004, Dasar dan Prinsip Pengawasan Bank, Jakarta: Gramedia Pustaka Utama, hlm. 8.

${ }^{5}$ Muhammad Syafiei Antonio, 2007, Bank Syariah: Dari Teori ke Praktik, Jakarta: Gema Insani Press, Cet. XI, hlm. 10-18. 
pengawasan terhadap lembaga keauangan yang dilakukan oleh dua lembaga independen yaitu Bank Indonesia selaku bank sentral dan Otoritas Jasa Keuangan (OJK) yang diberikan kewenangan untuk mengawasi. Berdasarkan uraian pada latar belakang diatas, maka masalah yang akan dibahas dalam penelitian ini adalah sebagai berikut:

1. Bagaimana pelaksanaan fungsi pengaturan dan pengawasan oleh Bank Indonesia terhadap perbankan setelah dibentuk OJK?

2. Bagaimana pelaksanaan fungsi pengaturan dan pengawasan oleh Otoritas Jasa Kewenangan (OJK) terhadap perbankan?

\section{Metodologi}

Berdasarkan segi fokus kajiannya, penelitian hukum dapat dibedakan menjadi tiga tipe yaitu penelitian hukum normatif, penelitian hukum normatif-empiris atau normatif-terapan, dan penelitian hukum empiris. ${ }^{6}$ Jenis Penelitian yang digunakan oleh penulis dalam penelitian ini yaitu jenis penelitian hukum normatif, yaitu penelitian hukum yang dilakukan dengan cara meneliti bahan pustaka, data sekunder atau penelitian hukum kepustakaan. ${ }^{7}$

Jenis penelitian hukum normatif digunakan karena fokus kajian dalam penelitian ini terkait dengan regulasi mengenai pelaksanaan fungsi pengaturan dan pengawasan oleh Bank Indonesia dan OJK terhadap perbankan di Indonesia. Untuk mendapatkan data dalam penelitian ini maka harus diambil dari berbagai sumber diantaranya bahan hukum primer (primary law material), bahan hukum sekunder (secondary law material) dan bahan hukum tersier (tertiary law material) yang berkaitan dengan fungsi pengawasan dari Bank Indonesia dan Otoritas Jasa Keuangan (OJK).

Pendekatan yang digunakan dalam penelitian ini adalah pendekatan Perundang-undangan atau Statute Approach. Pendekatan Statute Approach digunakan oleh penulis karena yang diteliti adalah terkait berbagai aturan hukum yang berkaitan dengan pelaksanaan fungsi pengaturan dan pengawasan yang dilakukan Bank Indonesia dan OJK yang telah diatur dalam peraturan perundang-undangan. Teknik pengumpulan data yang digunakan dalam penelitian ini adalah dengan studi kepustakaan. Studi kepustakaan dilakukan dengan cara mengumpulkan data yang terdapat dalam buku-buku, perundang-undangan, dokumen-dokumen, literatur, majalah serta makalah yang berhubungan dengan objek yang diteliti. ${ }^{8}$ Analisis data yang digunakan dalam penelitian hukum normatif adalah dengan menganalisis cara hlm. 52

${ }^{6}$ Abdulkadir Muhammad, 2004, Hukum Dan Penelitian Hukum, Bandung: Citra Aditya Bakti,

7 Soerjono Soekanto dan Sri Mamudji dalam Rustam Magun Pikahulan, Konsep Alih Teknologi Dalam Penanaman Modal Di Indonesia Bidang Industri Otomotif, Jurnal Cakrawala Hukum Vol. XIII No. 02 Tahun 2017, hlm. 78 diakses melalui https://ejournal.up45.ac.id/index.php/cakrawalahukum/article/view/385/342, pada tanggal 20 Februari 2020

8 Amiruddin dan Zainal Asikin, 2006, Pengantar Metode Penelitian Hukum, Jakarta: Raja Grafindo Persada, hlm. 18. 
data yang diperoleh, sehingga analisis data dalam penelitian ini mengunakan teknik analisis deskriptif kualitatif yaitu mengembangkan teori yang dibangun dari data yang didapat dari hasil penelitian yang telah memberikan gambaran-gambaran (deskripsi).

\section{Analisis dan Hasil}

\subsection{Fungsi Pengaturan Dan Pengawasan Oleh Bank Indonesia Terhadap Kinerja Perbankan.}

Sebelum berdirinya Otoritas Jasa Keuangan (OJK), tujuan pengawasan bank yang dilakukan oleh Bank Indonesia yaitu untuk menciptakan perbankan yang sehat yang dapat memenuhi tiga aspek, pertama memelihara kepentingan masyarakat, beroperasi dengan sehat dan efisien dan mampu memenuhi kewajibannya terhadap masyarakat penyimpan dana, kedua berkembang secara wajar dan mampu memberikan pelayanan yang diperlukan masyarakat Indonesia dan ketiga bermanfaat bagi perkembangan ekonomi Indonesia serta dapat menunjang pengendalian moneter dalam rangka menunjang pembangunan ekonomi dan tercapainya kestabilan moneter. ${ }^{9}$ Sistem pengawasan pada saat ini antara lain didasarkan pada prinsip prudential regulation approach dan risk based approach yang bertolak dari sikap kehatihatian dan mematuhi berbagai ketentuan kehati-hatian yang ditetapkan Bank Indonesia dan pengawasan berbasis risiko (risk based supervision) dimana bank harus mengidentikasi profil risiko dari seluruh kegiatan usahanya selanjutnya Bank Indonesia melakukan pengawasan sesuai dengan risk profile dari bank tersebut. Dalam bisnis perbankan, pengawasan tersebut pada umumnya dilaksanakan oleh otoritas pengawasan bank melalui kewenangan yang oleh undang-undang kepada satu tangan, yaitu Bank indonesia. ${ }^{10}$

Pada dasarnya pembinaan dan pengawasan bank oleh Bank Indonesia, dilaksanakan oleh otoritas pengawasan melalui empat kewenangan, yaitu kewenangan memberikan izin (power to license), kewenangan untuk mengatur (power to regulate), kewenangan untuk mengendalikan (power to control) dan kewenangan untuk mengenakan sanksi (power to impose sanction). ${ }^{11}$ Menurut ketentuan Undang-undang Nomor 23 Tahun 1999 tentang Bank Indonesia, pada pasal 7 sampai dengan pasal 35, antara lain ditegaskan bahwa : Bank Indonesia diberi tugas untuk menetapkan dan melaksanakan kebijakan moneter; mengatur dan menjaga kelancaran sistem pembayaran; serta mengatur dan mengawasi bank. Selanjutnya ditetapkan bahwa Bank Indonesia membina perbankan dengan jalan: memperluas, memperlancar dan mengatur lalu lintas pembayaran giral dan menyelenggarakan clearing antar bank;

\footnotetext{
${ }^{9}$ Maqdir Ismail, 2007, BANK INDONESIA Independensi, Akuntabilitas dan Transparansi, Fakultas Hukum Universitad Al-Azhar Indonesia (UAI), hlm. 20

$10 \mathrm{Ibid}, \mathrm{hlm} .21$.

11 Marulak Pardede, 2009, Aspek Hukum Pemisahan Pembinaan Dan Pengawasan Perbankan, JAKARTA: Badan Pembinaan Hukum Nasional Departemen Hukum Dan HAM - RI, hlm. 17
} 
menetapkan ketentuan-ketentuan umum tentang solvabilitas dan likuiditas bank-bank; memberikan bimbingan kepada bank-bank guna penatalaksanaan bank secara sehat.

Fungsi pengawasan yang terhadap perbankan yang dilakukan oleh BI beralih pada OJK pada akhir tahun 2011, sebagai upaya reformasi sektor keuangan melalui Pemerintah dan Dewan Perwakilan Rakyat (DPR) mendirikan lembaga pengawasan di bidang keuangan yaitu Otoritas Jasa Keuangan (OJK). Kemudian, pada tanggal 22 November 2011 disahkanlah Undang-undang Nomor 21 tentang Otoritas Jasa Keuangan. Otoritas Jasa Keuangan mulai beroperasi pada tanggal 31 Desember 2012 dengan mengambil alih sebagian tugas, fungsi dan wewenang pengawasan yang ada pada Badan Pengawas Pasar Modal. Hal ini sebagaimana ditegaskan dalam aturan pelarilan pasal 55 Undang-undang Nomor 21 Tahun 2011 tentang Otoritas Jasa Keuangan (OJK).

Pengawasan dan pengaturan yang dilakukan oleh Bank Indonesia sebelumnya adalah pengawasan universal yang bersifat macroprudential dan microprudential. Oleh karena itu, kewenangan yang dimiliki oleh Otoritas Jasa Keuangan saat ini merupakan pendelegasian kewenangan yang dimiliki oleh Bank Indonesia yang termasuk pada pasal 34 ayat (1) dan (2) Undang-undang Bank Indonesia. 12 Pada mulanya Bank Indonesia memiliki tugas dan wewenang berdasarkan Undang-undang Bank Indonesia yaitu terdapat pada pasal 8 yaitu: Untuk mencapai tujuan sebagaimana dimaksud dalam Pasal 7, Bank Indonesia mempunyai tugas sebagai berikut :

a. Menetapkan dan melaksanakan kebijakan moneter;

b. Mengatur dan menjaga kelancaran sistem pembayaran;

c. Mengatur dan mengawasi Bank

Fungsi pengaturan dan pengawasan yang dilakukan Bank Indonesia dengan hadirnya Otoritas Jasa Keuangan berdasarkan analisa penulis tidak dihilangkan, akan tetapi lebih tepatnya dikurangi. Hal ini dikarenakan, Pengawasan macroprudential tetap saja menjadi kewenagan dari Bank Indonesia. Hal ini sebagaimana diatur jelas dalam penjelasan Pasal 7 Undang-Undang OJK tentang tugas dan wewenang Bank Indonesia yaitu Adapun lingkup pengaturan dan pengawasan macroprudential, yakni pengaturan dan pengawasan selain hal yang diatur dalam pasal ini, merupakan tugas dan wewenang Bank Indonesia. Dalam rangka pengaturan dan pengawasan macroprudential, OJK membantu Bank Indonesia untuk melakukan himbauan moral (moral suasion) kepada Perbankan.

Pengawasan macroprudential yang dimaksud disini yaitu untuk mengatur stabilitas sistem keuangan secara keseluruhan dan secara komprehensif mempersiapkan terjadinya risiko sistemik di sektor keuangan dengan upaya membatasi dampak berantai terhadap keseluruhan ekonomi Negara. Tujuan dari

12 M Jeffri Arlinandes Chandra, 2015, Kewenangan Bank Indonesia Dalam Pengaturan Dan Pengawasan Perbankan Setelah Terbitnya Undang-Undang No 21 Tahun 2011 tentang Otoritas Jasa Keuangan, Jurnal Hukum Sehasen, Vol.1 No.1 Tahun 2015, hlm. 27 
macroprudential supervision adalah untuk meminimalkan dampak krisis keuangan pada perekonomian suatu negara, antara lain dengan cara menginformasikan kepada otoritas publik dan industri keuangan apabila terdapat potensi ketidakseimbangan di sejumlah institusi keuangan serta melakukan penilaian mengenai potensi dampak kegagalan institusi keuangan terhadap stabilitas sistem keuangan suatu negara.

Jadi Macroprudential supervision yang menjadi kewenangan Bank Indonesia tetap harus bekerjasama OJK dan terfokus pada aktivitas lembaga-lembaga keuangan yang memiliki pengaruh signifikan pada pasar maupun sistem keuangan. Macroprudential surveillance menyediakan sarana untuk memonitor dan mengatasi berbagai risiko yang akan mengancam stabilitas sistem keuangan dan ekonomi riil secara keseluruhan. Selain itu, macroprudential surveillance juga dapat menyajikan penjelasan mengenai risiko sistemik dan mitigasi dampak rembetan dari guncangan yang terjadi pada institusi keuangan yang dapat menggangu siklus bisnis. Informasi dari Macroprudential supervision akan membantu para pembuat kebijakan mengenai perlunya bail-out (atau tidak) terhadap suatu institusi keuangan yang tengah mengalami kesulitan likuiditas. ${ }^{13}$

Jadi menurut, Bismar Nasution, macroprudential supervision adalah mengarahkan dan mendorong bank serta sekaligus mengawasinya agar dapat ikut berperan dalam program pencapaian sasaran ekonomi makro, baik yang terkait dengan kebijaksanaan umum untuk mendorong pertumbuhan ekonomi, kemantapan neraca pembayaran, perluasan lapangan kerja, kestabilan moneter, maupun upaya pemerataan pendapatan dan kesempatan berusaha. Sedangkan tujuan dari microprudential supervision adalah mengupayakan agar setiap bank secara individual sehat dan aman, serta keseluruhan industri perbankan menjadi sehat dan dapat memelihara kepercayaan masyarakat. Tugas pengawasan Bank Indonesia terhadap perbankan dalam lingkup makroprudensial, Bank Indonesia melakukan pemeriksaan langsung kepada bank tertentu yang tergolong ke dalam Systemically Important Bank dan/atau bank lainnya sesuai dengan kewenangan Bank Indonesia di bidang makroprudensial. Kemudian Bank Indonesia juga dapat melakukan langkah-langkah penyehatan terhadap bank yang mengalami kesulitan likuiditas atau kondisi kesehatan yang semakin memburuk. ${ }^{14}$

Lebih jelasnya lagi dalam hal pengaturan dan pengawasan OJK maupun Bank Indonesia tetap harus berkordinasi. Hal ini dapat dilihat dalam Pasal 40 Undangundang tentang OJK yang mempertegas bahwa, untuk kewenangan Bank Indonesia dalam perbankan terdapat pada:

13https:/ / business-law.binus.ac.id/2016/07/30/tugas-dan-wewenang-antara-bank-indonesiadengan-otoritas-jasa-keuangan-tehadap-sektor-keuangan-bagian-2-dari-2-tulisan/, diakses pada tanggal 08 Agustus 2019 Pukul 15:14 WITA

14 Metia Winati Muchda, Maryati Bachtiar dan Dasrol, 2014, Pengalihan Tugas Pengaturan Dan Pengawasan Perbankan Dari Bank Indonesia Kepada Otoritas Jasa Keuangan Berdasarkan Undang-Undang Nomor 21 Tahun 2011 Tentang Otoritas Jasa Keuangan, JURNAL EKONOMI Volume 22, Nomor 2 Juni 2014. 
a. Bank Indonesia untuk melaksanakan fungsi, tugas, dan wewenangnya memerlukan pemeriksaan khusus terhadap bank tertentu, Bank Indonesia dapat melakukan pemeriksaan langsung terhadap bank tersebut dengan menyampaikan pemberitahuan secara tertulis terlebih dahulu kepada OJK.

b. Bank Indonesia tidak dapat memberikan penilaian terhadap tingkat kesehatan bank.

c. Dalam hal OJK mengindikasikan bank tertentu mengalami kesulitan likuiditas dan/atau kondisi kesehatan semakin memburuk, OJK segera menginformasikan ke Bank Indonesia untuk melakukan langkahlangkah sesuai dengan kewenangan Bank Indonesia.

\subsection{Fungsi Pengaturan Dan Pengawasan Oleh Otoritas Jasa Kewenangan (OJK)} Terhadap Perbankan

Dalam menjalankan tugas pengawasan bank, saat ini OJK melaksanakan sistem pengawasannya dengan menggunakan dua pendekatan. Yang pertama Pengawasan Berdasarkan Kepatuhan (Compliance Based Supervision/CBS), yaitu pemantauan kepatuhan bank terhadap ketentuan-ketentuan yang terkait dengan operasi dan pengelolaan bank di masa lalu dengan tujuan untuk memastikan bahwa bank telah beroperasi dan dikelola secara baik dan benar menurut prinsip-prinsip kehati-hatian. Pengawasan terhadap pemenuhan aspek kepatuhan merupakan bagian yang tidak terpisahkan dari pelaksanaan Pengawasan Bank berdasarkan Risiko. Dan yang kedua adalah Pengawasan Berdasarkan Risiko (Risk Based Supervision/RBS), yaitu pengawasan bank yang menggunakan strategi dan metodologi berdasarkan risiko yang memungkinkan pengawas bank dapat mendeteksi risiko yang signifikan secara dini dan mengambil tindakan pengawasan yang sesuai dan tepat waktu. ${ }^{15}$

a. Kedudukan hukum Otoritas Jasa Keuangan (OJK) ditetapkan sebagai lembaga yang independen dalam melaksanakan tugas dan wewenangnya untuk mengawasi kinerja dari lembaga keuangan dalam hal ini termasuk perbankan harus bebas dari campur tangan pihak lain Pengaturan dan pengawasan mengenai kelembagaan bank yang meliputi:

1) Perizinan untuk pendirian bank, pembukaan kantor bank, anggaran dasar, rencana kerja, kepemilikan, kepengurusan, dan sumber daya manusia, merger, konsolidasi, dan akuisisi bank, serta pencabutan izin usaha bank; dan

2) Kegiatan usaha bank, antara lain: sumber dana, penyediaan dana, produk hibridasi, dan aktivitas di bidang jasa.

b. Pengaturan dan pengawasan mengenai kesehatan bank yang meliputi:

15 Uswatun Hasanah, 2017, Hukum Perbankan, Malang: Setara Press, hlm. 45 
1) Likuiditas, rentabilitas, solvabilitas, kualitas aset, rasio kecukupan modal minimum, batas maksimum pemberian kredit, rasio pinjaman terhadap simpanan, dan pencadangan bank;

2) Laporan bank yang terkait dengan kesehatan dan kinerja bank;

3) Sistem informasi debitur;

4) Pengujian kredit (credit testing); dan

5) Standar akuntansi bank.

c. Pengaturan dan pengawasan mengenai aspek kehati-hatian bank, meliputi:

1) Manajemen risiko;

2) Tata kelola bank;

Prinsip mengenal nasabah. Dikecualikan untuk hal tertentu yang diatur tegas dalam Undang-undang Nomor 21 Tahun 2011 tentang Otoritas Jasa Keuangan (OJK). Pasal 7 Undang-undang Otoritas Jasa Keuangan menyebutkan bahwa, untuk melaksanakan tugas pengaturan dan pengawasan di sektor Perbankan sebagaimana dimaksud dalam Pasal 6 huruf a Undang-Undang Otoritas Jasa Keuangan, Otoritas Jasa Keuangan mempunyai wewenang:

3) anti pencucian uang; dan

4) Pencegahan pembiayaan terorisme dan kejahatan perbankan.

Fungsi Otoritas Jasa Keuangan sebagai regulator adalah penyelengaraan sistem pengaturan dan pengawasan yang terintegrasi terhadap keseluruhan kegiatan di sektor keuangan. Oleh karena itu maka, keseluruhan kegiatan jasa keuangan yang dilakukan oleh lembaga lembaga keuangan dalam hal ini termasuk perbankan harus tunduk pada sistem pengaturan dan pengawasan Otoritas Jasa Keuangan. Hal ini sebagaimana di tegaskan dalam Pasal 6 UndangUndang tahun 2011 tentang Otoritas Jasa Keuangan menyebutkan bahwa Otoritas Jasa Keuangan melaksanakan tugas pengaturan dan pengawasan terhadap:

a. Kegiatan jasa keuangan di sektor perbankan;

b. Kegiatan jasa keuangan di sektor Pasar Modal; dan

c. Kegiatan jasa keuangan di sektor Perasuransian, Dana Pensiun, Lembaga Pembiayaan, dan Lembaga Jasa Keuangan Lainnya.

\section{Kesimpulan}

Berdasarkan pada pembahasan diatas maka dapat disimpulkan bahwa:

1. Fungsi pengaturan dan pengawasan yang dilakukan Bank Indonesia dengan hadirnya Otoritas Jasa Keuangan (OJK) secara yuridis tetaplah ada. Hal ini dikarenakan, Pengawasan macroprudential tetap saja menjadi kewenagnan Bank Indonesia. Sebagaimana diatur dalam penjelasan Pasal 7 Undang-Undang OJK tentang tugas dan wewenang Bank Indonesia meliputi lingkup pengaturan dan pengawasan macroprudential, yakni pengaturan dan pengawasan selain hal 
yang diatur dalam pasal ini, merupakan tugas dan wewenang Bank Indonesia. Dalam rangka pengaturan dan pengawasan macroprudential, OJK membantu Bank Indonesia untuk melakukan himbauan moral (moral suasion) kepada Perbankan.

2. Secara yuridis, fungsi Otoritas Jasa Keuangan (OJK) adalah penyelengaraan sistem pengaturan dan pengawasan yang terintegrasi terhadap keseluruhan kegiatan di sector keuangan termasuk pada sektor perbankan. Oleh karena itu maka, keseluruhan kegiatan jasa keuangan yang dilakukan oleh Lembagalembaga keuangan termasuk perbankan harus tunduk pada sistem pengaturan dan pengawasan Otoritas Jasa Keuangan. Hal ini sebagaimana di tegaskan dalam Pasal 6 Undang-Undang tahun 2011 tentang Otoritas Jasa Keuangan menyebutkan bahwa Otoritas Jasa Keuangan adalah melaksanakan tugas pengaturan dan pengawasan salah satunya adalah kegiatan jasa keuangan di sektor perbankan.

\section{Daftar Pustaka}

\section{Buku}

Abdulkadir Muhammad, (2004), Hukum Dan Penelitian Hukum, Bandung: Citra Aditya Bakti

Departemen Kajian dan Aksi Strategis BEM FEUI, (2014) Kajian Pro-Kontra Hadirnya Otoritas Jasa Keuangan di Indonesia, Depok: BEM FE UI

Irham Fahmi, (2014), Bank E Lembaga Keuangan Lainnya, Bandung: Alfabeta.

Maqdir Ismail, (2007) ,BANK INDONESIA Independensi, Akuntabilitas dan Transparansi, Fakultas Hukum Universitas Al-Azhar Indonesia (UAI).

Marulak Pardede, (2009), Aspek Hukum Pemisahan Pembinaan Dan Pengawasan Perbankan, JAKARTA: Badan Pembinaan Hukum Nasional Departemen Hukum Dan HAM - RI.

Muhammad Djumhana, (2006), Hukum Perbankan di Indonesia, Bandung: Citra Aditya Bakti, cetakan. ke v.

Muhammad Syafici Antonio, (2007), Bank Syariah: Dari Teori ke Praktik, Jakarta: Gema Insani Press, Cet. XI.

Permadi Gandapradja, (2004), Dasar dan Prinsip Pengawasan Bank, Jakarta: Gramedia Pustaka Utama.

Sihombing, Jonker, (2012), Otoritas Jasa Keuangan : Konsep,Regulasi dan Implementasi, Jakarta:Ref Publisher.

Siti Sundari, Laporan Kompendium Hukum Bidang Perbankan, (Kementrian Hukum dan HAM RI, 2011)

Sugiyono, F.X dan Ascarya, (2004), Bank Indonesia Bank Sentral Republik Indonesia Sebuah Pengantar : Kelembagaan Bank Indonesia, Jakarta: Pusat Pendidikan Dan Studi Kebanksentralan Bank Indonesia.

Uswatun Hasanah, (2017), Hukum Perbankan, Malang: Setara Press. 


\section{Jurnal \& Website:}

Lina Maulidiana, Fungsi Otoritas Jasa Keuangan Sebagai Lembaga Pengawas Perbankan Nasional Di Indonesia, Jurnal KEADILAN PROGRESIF Volume 5 Nomor 1 Maret 2014

Metia Winati Muchda, Maryati Bachtiar dan Dasrol, 2014, Pengalihan Tugas Pengaturan Dan Pengawasan Perbankan Dari Bank Indonesia Kepada Otoritas Jasa Keuangan Berdasarkan Undang-Undang Nomor 21 Tahun 2011 Tentang Otoritas Jasa Keuangan, JURNAL EKONOMI Volume 22, Nomor 2 Juni 2014.

M Jeffri Arlinandes Chandra, 2015, Kewenangan Bank Indonesia Dalam Pengaturan Dan Pengawasan Perbankan Setelah Terbitnya Undang-Undang No 21 Tahun 2011 Tentang Otoritas Jasa Keuangan, Jurnal Hukum Sehasen Vol.1 No.1 Tahun 2015.

Soerjono Soekanto dan Sri Mamudji dalam Rustam Magun Pikahulan, Konsep Alih Teknologi Dalam Penanaman Modal Di Indonesia Bidang Industri Otomotif, Jurnal Cakrawala Hukum Vol. XIII No. 02 Tahun 2017, hlm. 78 diakses melalui https:// ejournal.up45.ac.id/index.php/cakrawalahukum/article/view/385/342, pada tanggal 20 Februari 2020

Surti Yustiantia, Kewenangan Pengaturan Dan Pengawasan Perbankan Oleh Bank Indonesia Dan Otoritas Jasa Keuangan (Ojk), Acta Diurnal Volume 1, Nomor 1, Desember 2017

Zulfi Diane Zaini, "Hubungan Hukum Bank Indonesia Sebagai Bank Sentral Dengan Otoritas Jasa Keuangan (OJK) Pasca Pengalihan Fungsi Perbankan", Jurnal Media Hukum, Vol. 20 No. 2, Desember 2013.

https:/ / business-law.binus.ac.id/2016/07/30/tugas-dan-wewenang-antara-bankindonesia-dengan-otoritas-jasa-keuangan-tehadap-sektor-keuangan-bagian-2dari-2-tulisan/

\section{Undang-Undang:}

Undang-undang Nomor 23 Tahun 1999 tentang Bank Indonesia

Undang-Undang Nomor 3 Tahun 2004 tentang Perubahan Atas Undang-undang Nomor 23 Tahun 1999 tentang Bank Indonesia (BI).

Undang-Undang Nomor 21 Tahun 2011 Tentang Otoritas Jasa Keuangan 